\title{
Brain biomarkers in tench (Tinca tinca L.) after semi-static exposure to the pesticide carbofuran
}

\author{
Biomarcadores cerebrales en tenca (Tinca tinca L.) tras una exposición semiestática al pesticida \\ carbofurano
}

\section{Biomarcadores cerebrais na tenca (Tinca tinca L.) após uma exposição semi-estática ao pesticida carbofurano}

David Hernández-Moreno ${ }^{1}$; María Gil-Molinos ${ }^{1}$; Simone Bertini²; María Prado Míguez ${ }^{1,3}$; Francisco Soler-Rodríguez ${ }^{1,4}$; Marcos Pérez-López ${ }^{1,3 *}$.

${ }^{1}$ Área de Toxicología, Facultad de Veterinaria (UEX), 10003 Cáceres (España).

${ }^{2}$ Dipartimento di Scienze Medico-Veterinarie. Universitá di Parma (Italia).

${ }^{3}$ INBIO (Instituto Universitario de Biotecnología Ganadera y Cinegética, UEX)

${ }^{4}$ IPROCAR G+C (Instituto Universitario de Carne y Productos Cárnicos, UEX), Institutos de investigación (UEX).

(Received: January 15, 2018; accepted: February 1, 2019)

To cite this article:

Hernández-Moreno D, Gil Molinos M, Bertini S, Míguez MP, Soler-Rodriguez F, Pérez-López M. Brain biomarkers in tench (Tinca tinca L.) after semi-static exposure to the pesticide carbofuran. Rev Colomb Cienc Pecu 2019; 32(3):232-244.

DOI: https://doi.org/10.17533/udea.rccp.v32n3a08

* Corresponding author: Avda de la Universidad s/n, 10003 Cáceres (España). E-mail: marcospl@unex.es 


\section{Abstract}

Background: The aquatic environment is continuously being contaminated with toxic chemical substances from industrial, agricultural and domestic activities. The identification of different biomarkers of such contamination is of great relevance to determine the potential impact of those xenobiotics on the health of organisms. Objectives: To estimate the suitability of different biochemical brain biomarkers from tench in order to evaluate the environmental effect of an exposition to different concentrations of the pesticide carbofuran. Methods: The present study focused on the effect of a long-term exposure (28 days) to different concentrations $(50,100$ and $200 \mu \mathrm{g} / \mathrm{L})$ of the pesticide carbofuran on certain biochemical parameters of tench (Tinca tinca L.). Selected biomarkers for stress monitoring were malondialdehyde (MDA), as index of lipid peroxidation, and reduced glutathione (GSH). Moreover, acetylcholinesterase (AChE) activity was quantified as biomarker of effect on fish nervous system. Results: AChE activity was significantly inhibited in fish exposed to all concentrations of carbofuran after 14 and 21 days of exposure, returning to basal levels after this period with 50 and $100 \mu \mathrm{g} / \mathrm{L}$. Moreover, significant decreases of MDA levels could be detected after 14 and 21 days of exposure to $200 \mu \mathrm{g} / \mathrm{L}$, lasting until the end of the experiment. GSH levels decreased after 14 and 21 days of exposure to 100 and $200 \mu \mathrm{g} / \mathrm{L}$; nevertheless, GSH recovered basal levels at the end of the experiment. Conclusion: All the three biochemical parameters assessed -mainly inhibition of AChE activity- could be adequate biomarkers of early exposition (less than 14 days) to low doses of carbofuran in biomonitoring programs, being MDA reduction also related to longer exposure.

Keywords: biomarkers; carbamate; ecotoxicology; fish; lipid peroxidation; pesticide; tench; xenobiotics.

\section{Resumen}

Antecedentes: El ambiente acuático está continuamente contaminado con sustancias químicas tóxicas provenientes de actividades industriales, agrícolas y domésticas. La identificación de diferentes biomarcadores de dicha contaminación es de gran relevancia para determinar el impacto potencial de esos xenobióticos en la salud de los organismos. Objetivo: Estimar la idoneidad de diferentes biomarcadores cerebrales bioquímicos de tenca para evaluar el efecto ambiental de una exposición a diferentes concentraciones del pesticida carbofurano. Método: El presente estudio se centró en los efectos de una exposición a largo plazo (28 días) a diferentes concentraciones $(50,100$ y $200 \mu \mathrm{g} / \mathrm{L})$ del pesticida carbofurano sobre determinados parámetros bioquímicos de la tenca (Tinca tinca L.). Los biomarcadores seleccionados para el control del estrés fueron el malondialdehído (MDA), como indicador de peroxidación lipídica, y el glutatión reducido (GSH). Además, se cuantificó la actividad acetilcolinesterasa (AChE), como biomarcador de efecto sobre el sistema nervioso del pez. Resultados: La actividad AChE se inhibió significativamente en los peces expuestos a todas las concentraciones de carbofurano después de 14 y 21 días de exposición, regresando a los niveles basales tras este periodo en las exposiciones con 50 y $100 \mu \mathrm{g} / \mathrm{L}$. Así mismo se detectaron descensos significativos de los niveles de MDA tras 14 y 21 días de exposición con $200 \mu \mathrm{g} / \mathrm{L}$, manteniéndose hasta el final del experimento. Los niveles de GSH descendieron tras 14 y 21 días de exposición con 100 y 200 g/l; sin embargo, los niveles basales se recuperaron al final del experimento. Conclusión: Los tres parámetros bioquímicos evaluados, pero principalmente la inhibición de la actividad de AChE, podrían usarse como biomarcadores de exposición temprana (menos de 14 días) a bajas dosis de carbofurano en programas de biomonitorización, estando la reducción de MDA también relacionada con exposiciones más prolongadas.

Palabras clave: biomarcadores; carbamato; ecotoxicología; peces; peroxidación lipídica; pesticida; pez; tenca; xenobióticos.

\section{Resumo}

Antecedentes: O meio aquático está sendo continuamente contaminado com substâncias químicas tóxicas de atividades industriais, agrícolas e domésticas. A identificação de diferentes biomarcadores de tal contaminação é de grande relevância para determinar o impacto potencial desses xenobióticos na saúde dos organismos. Objetivo: Estimativa da idoneidade de várias biomarcadores cerebrais bioquímicos de tenca para avaliar o efeito ambiental de uma exposição a diferentes concentrações do pesticida carbofurano. Método: O presente estudo centrou-se no efeito de uma exposição a longo prazo (28 dias) a diferentes concentrações (50, 100 e $200 \mu \mathrm{g} / \mathrm{L})$ do pesticida carbofurano em certos parâmetros bioquímicos da tenca (Tinca tinca L.). Os biomarcadores selecionados para o monitoramento do estresse foram malondialdeído (MDA), como índice de peroxidação lipídica e glutationa reduzida (GSH). Além disso, a atividade da acetilcolinesterase (AChE) foi 
quantificada, como biomarcador de efeito sobre o sistema nervoso do peixe. Resultados: A atividade de AChE foi significativamente inibida em peixes expostos a todas as concentrações de carbofurano após 14 e 21 dias de exposição, voltando aos níveis basais após esse período com 50 e $100 \mu \mathrm{g} / \mathrm{L}$. Além disso, as diminuições significativas dos níveis de MDA podem ser detectadas após 14 e 21 dias de exposição a $200 \mu \mathrm{g} / \mathrm{L}$, até o final do experimento. Os níveis de GSH diminuíram após 14 e 21 dias de exposição a 100 e $200 \mu \mathrm{g} / \mathrm{L}$, porém GSH recuperou os níveis basais no final do experimento. Conclusão: Todos os três parâmetros bioquímicos avaliados, mas principalmente a inibição da atividade AChE, podem ser biomarcadores adequados de exposição precoce (menos de 14 dias) a baixas doses de carbofurano em programas de biomonitorização, sendo a redução de MDA também relacionada a exposições mais longas.

Palavras-chave: biomarcadores; carbamato; ecotoxicologia; peroxidação lipídica; peixe; pesticida; tenca; xenobioticos.

\section{Introduction}

Carbofuran (2,3-dihydro-2,2-dimethylbenzofuran7-yl methylcarbamate, CAS number 1563-66-2) is a broad-spectrum systemic insecticide, nematicide and acaricide with a low residual effect, used worldwide. In 2007, authorizations for products containing carbofuran in the EU were cancelled because of the impact on human health and the environment. The specific toxicodynamic of this carbamate is associated to the inhibition of the enzyme acetylcholinesterase (AChE) and the neuronal synapses in the central nervous system. Therefore, AChE has been used in various biomonitoring programs, considered as one of the best indicators of effect on either acute or chronic exposure to piscine species (Li et al., 2011; Chen et al., 2012).

Disturbance in the oxidation/anti-oxidation balance is one of the main changes caused by carbamate pesticides (Abdollahi et al., 2004). This disturbance is called oxidative stress and carbamates induce it by catalyzing the conversion of oxygen to reactive oxygen species (ROS), which accumulate and overcome cellular and tissue antioxidant defenses. Lipid peroxidation (LPO) is a marker of effect, which reflects the action of ROS in biological lipids, and can be measured by the presence of a lipid metabolite, being malondialdehyde (MDA) the most representative decomposition product of lipoperoxides (Livingstone, 2001). Similarly, reduced glutathione (GSH) has several important functions, including protection against oxidative stress metabolites (Kanno et al., 2003).

Fish respond to environmental stress through a variety of compensatory mechanisms, adapting their metabolic functions (Eissa et al., 2003), thus being good indicators of environmental quality. A possible example would be the tench, Tinca tinca L., which may constitute an adequate organism for biomonitoring in Southern Europe, as it is widely distributed in most small bodies of water, acting as bioindicators of regional environmental pollution in the whole water column due to their special behavior (Hernández-Moreno et al., 2008).

Brain has been reported as the most sensitive organ to an oxidative damage (Song et al., 2006), as well as the main reservoir for acetylcholinesterase. In the present study, the effect of different sublethal concentrations of carbofuran in brain of tenchs exposed under semi-static flow conditions for 28 days (long-term toxicity) was assessed. The effect after 7 , 14 and 21 days of exposure was also studied. The objective was to determine the variations caused by such exposure in different biochemical parameters (oxidative stress and cholinesterase activity) of tench, in an attempt to establish parameters of early detection of pollution in a static polluted environment.

\section{Materials and Methods}

\section{Ethical considerations}

All procedures were performed in compliance with relevant laws and institutional guidelines concerning experimental animals.

\section{Chemicals}

All the chemicals and reagents (analytical grade) used were supplied by Sigma-Aldrich (Germany). 
Technical carbofuran (CF) (95\% product) was provided by Faesal-Spain. Stock solution was prepared by dissolving pesticide in $1 \mathrm{~mL}$ of absolute ethanol in a standard volumetric flask. The amount of solvent in the aquaria was negligible.

\section{Animals}

Tenchs of both genders (mean weight $20 \pm 11 \mathrm{~g}$ ) were obtained from a local fish hatchery ("Piscifactorías del Guadiana" in Badajoz, Spain). Animals ( $\mathrm{N}=140)$ were transported in aerated water to the Toxicology Unit (Extremadura University, Spain) and randomly divided into four groups of 35 fish. Every group was placed into an isolated glass aquarium fitted with recirculated, dechlorinated and aerated tap water at $20 \pm 2{ }^{\circ} \mathrm{C}$. All animals were acclimated to laboratory conditions for 14 days prior the initiation of the study to reduce differences associated to stress, and were fed once daily with a commercial dry diet (OVN Dibaq-Diproteg, Segovia, Spain) until the end of the experiment. Water quality characteristics during all the experience were determined according to APHA (APHA/AWWA/WPCF, 1992). A 10-hours light controlled photoperiod was maintained.

\section{Exposure}

As indicated, fish were divided into 4 groups: one control and three experimental treatments. Each experimental group was exposed to a different sublethal concentration of pesticide $(50,100$ and 200 $\mu \mathrm{g} / \mathrm{L}$ ) for 28 days, and more specifically, the lowest concentration used in this experiment corresponded to the concentration recommended in different countries for use in crop cultures (Clasen et al., 2014). Water in each aquarium was gently siphoned out twice a week and replaced with the same concentrations of pesticide to clean the water and preserve the pesticide concentration stable.

Water samples $(250 \mathrm{~mL})$ were taken once a week from each tank for carbofuran analysis to assess the effective concentrations of the pesticide by using a HPLC technique with acetonitrile and water as mobile phase and a Nucleosyl 120 C18 column (HernándezMoreno et al., 2008). Calibrations were performed analyzing several samples of carbofuran at known concentrations. Carbofuran was also analyzed in muscle samples. Exposed and control animals ( $\mathrm{n}=7$ from each aquarium) were removed at the beginning of the experiment and at 7, 14, 21 and 28 days. A number of animals greater than 4 was taken from every aquarium at every sampling day, in agreement with the proposal for bioconcentration tests in continuous flow conditions (OECD, 1996), and each animal was considered a replicate. Fish were starved for $24 \mathrm{~h}$ before sacrifice.

Fish were anesthetized with a solution of MS222 (Sigma) at a concentration of $0.1 \mathrm{~g} / \mathrm{L}$ (HernándezMoreno et al., 2008). Animals were killed, and their brain was immediately dissected, weighed, measured and individually frozen at $-80{ }^{\circ} \mathrm{C}$ until biochemical assays. Liver was taken to evaluate hepatosomatic index.

\section{Biochemical measurements}

Brain was homogenized in cold potassium phosphate buffer $(100 \mathrm{mM}, \mathrm{pH} 7.4)$ at a concentration of $1 \mathrm{~g} / 5 \mathrm{~mL}$. The homogenate was centrifuged at 3,000 rpm for $5 \mathrm{~min}$ at $4{ }^{\circ} \mathrm{C}$ to obtain the supernatant, where $\mathrm{AChE}$ activity was measured. An aliquot of brain homogenate was used to determine the extent of endogenous LPO and GSH levels after treatment with perchloric acid and a second centrifugation $\left(4,000 \mathrm{rpm}\right.$ for $15 \mathrm{~min}$ at $\left.4{ }^{\circ} \mathrm{C}\right)$.

AChE activity was determined spectrophotometrically at $405 \mathrm{~nm}, 42^{\circ} \mathrm{C}$, according to the Ellman method (Ellman et al., 1961), adapted to a microplate, following the general procedure described by Thompson (1999), and expressed as Units (U) per $\mathrm{mg}$ of protein ( $1 \mathrm{U}$ is equal to 1 nmol acetylcholine hydrolyzed per min). A FL600 microplate reader (Bio-Tek ${ }^{\circledR}$, Winooski, VT, USA) was used to these purposes, since Tor et al. (1994) demonstrated the ability of a 96-well microplate reader for routine determinations of enzyme activity with sensitive, accurate, reproducible, and widely applicable results.

Accumulation of MDA was used as an index of lipid peroxidation and evaluated spectrophotometrically at $550 \mathrm{~nm}$ by measuring the presence of thiobarbituric acid reactive substances, according to the method proposed by Recknagel et al. (1982), using the microplate reader previously indicated. GSH levels were measured using a fluorometric method (Hissin and Hilf, 1976) at $350 \mathrm{~nm}$ 
excitation and $425 \mathrm{~nm}$ emission. In all cases, protein content in the homogenates was estimated by the Bradford method (Bradford, 1976) using bovine serum albumin as standard.

\section{Statistical analyses}

The SPSS software version 15.0 for Windows was used for data processing. Data were analyzed with one-way analysis of variance (ANOVA). In cases of significant differences, the ANOVA was followed by the LSD (Least Significant Difference) post-hoc test. Data were expressed as mean \pm S.E. Significant limit was set up at $p<0.05$. A Pearson's correlation test was also carried out.

\section{Results}

Water quality was analysed in order to maintain fish under controlled conditions. Temperature, $\mathrm{pH}$, alkalinity, conductivity and hardness of aquatic media averaged $20-23.2{ }^{\circ} \mathrm{C}, 7.8 \pm 0.5$ (Crison pHmeter, Crison Instruments, Barcelona, Spain), $3.5 \pm 0.64 \mathrm{mmol} / \mathrm{L}, 0.52-0.76 \mathrm{mOhm}$ and $160 \pm 41$ $\mathrm{mg} / \mathrm{L}$ (as $\mathrm{CaCO}_{3}$ ), respectively, and dissolved oxygen content was never below $5 \mathrm{mg} / \mathrm{L}$. Fish were weighed and sized; obtaining means ( \pm S.E.) of $65.04 \pm 7.81 \mathrm{~g}$ and $15.13 \pm 0.25 \mathrm{~cm}$, respectively. Statistical analysis demonstrated a lack of significant difference among fish related to these biometric parameters (Table 1).

Table 1. Mean value \pm SEM for the hepatosomatic index $(\mathrm{hsi})$, weight $(\mathrm{g})$ and length $(\mathrm{cm})$ of tenchs sampled at the beginning of the experiment and at 7,14, 21 and 28 days of exposure.

\begin{tabular}{|c|c|c|c|c|}
\hline Days of Assay & Concentration & hsi & Weight (mg) & Length $(\mathrm{cm})$ \\
\hline 0 & Control & $1.47 \pm 0.11$ & $70.71 \pm 11.01$ & $14.86 \pm 0.36$ \\
\hline \multirow{4}{*}{7} & Control & $0.98 \pm 0.13$ & $66.29 \pm 11.86$ & $15.49 \pm 1.34$ \\
\hline & $50 \mu \mathrm{g} / \mathrm{L}$ & $1.24 \pm 0.10$ & $69.43 \pm 8.77$ & $15.40 \pm 0.61$ \\
\hline & $100 \mu \mathrm{g} / \mathrm{L}$ & $1.07 \pm 0.09$ & $68.71 \pm 7.83$ & $14.94 \pm 0.37$ \\
\hline & $200 \mu \mathrm{g} / \mathrm{L}$ & $1.02 \pm 0.06$ & $77.86 \pm 16.41$ & $15.30 \pm 1.09$ \\
\hline \multirow{4}{*}{14} & Control & $1.73 \pm 0.18$ & $67.00 \pm 17.75$ & $15.30 \pm 0.47$ \\
\hline & $50 \mu \mathrm{g} / \mathrm{L}$ & $2.14 \pm 0.37$ & $47.86 \pm 2.88$ & $14.90 \pm 0.47$ \\
\hline & $100 \mu \mathrm{g} / \mathrm{L}$ & $3.65 \pm 1.38$ & $53.71 \pm 8.94$ & $14.50 \pm 0.64$ \\
\hline & $200 \mu \mathrm{g} / \mathrm{L}$ & $1.54 \pm 0.11$ & $51.43 \pm 10.53$ & $15.50 \pm 0.62$ \\
\hline \multirow{4}{*}{21} & Control & $1.20 \pm 0.05$ & $70.57 \pm 8.67$ & $14.80 \pm 0.72$ \\
\hline & $50 \mu \mathrm{g} / \mathrm{L}$ & $1.08 \pm 0.07$ & $71.86 \pm 8.53$ & $15.64 \pm 0.58$ \\
\hline & $100 \mu \mathrm{g} / \mathrm{L}$ & $1.15 \pm 0.06$ & $73.71 \pm 10.24$ & $15.84 \pm 0.58$ \\
\hline & $200 \mu \mathrm{g} / \mathrm{L}$ & $1.03 \pm 0.06$ & $59.71 \pm 4.75$ & $14.40 \pm 0.37$ \\
\hline \multirow{4}{*}{28} & Control & $1.84 \pm 0.21$ & $55.57 \pm 14.40$ & $14.97 \pm 0.90$ \\
\hline & $50 \mu \mathrm{g} / \mathrm{L}$ & $1.28 \pm 0.10$ * & $65.14 \pm 6.17$ & $14.84 \pm 0.46$ \\
\hline & $100 \mu \mathrm{g} / \mathrm{L}$ & $0.83 \pm 0.04$ * & $81.32 \pm 5.44$ & $14.78 \pm 0.29$ \\
\hline & $200 \mu \mathrm{g} / \mathrm{L}$ & $0.88 \pm 0.09$ * & $77.57 \pm 9.75$ & $15.83 \pm 0.69$ \\
\hline
\end{tabular}

* Statistically significant when compared to the control $(p<0.05)$. 
The hepatosomatic index was altered after the last day of exposure to all the carbofuran concentrations, being statistically decreased $(\mathrm{p}<0.05)$ compared to the control. Since no changes were observed during the rest of the experiment (Table 1), it seems that the normal hepatopancreas development was only affected after a long exposure to the pesticide.

According to the conditions established by the OCDE guidelines for testing of chemicals with fish, the bioassay performed with tench exposed to carbofuran was considered valid, since no mortality was observed in the control group; the variation of $\mathrm{pH}$ values was always lower than $1 \mathrm{pH}$ unity. Moreover, there was neither mortality nor nervous symptoms in any of the fish groups for the duration of the experiment.
Carbofuran residues were monitored in the water of the laboratory tanks to verify the presence of the active ingredient in the water. The test of water samples showed values around $90 \%$ in the nominal concentrations, assuming that fish were exposed to desired concentrations of carbofuran, during the whole experiment.

With respect to muscle samples, they were processed with dichloromethane and purified through a gel column to obtain extracts for injection in GC-MS. As an example, Figure 1 shows the profiles after injection of a sample from a tench exposed to $100 \mu \mathrm{g} / \mathrm{L}$ of carbofuran, with a clear peak appearing after 14.787 min easily related to carbofuran when observing the mass spectrum (Figure 2). Therefore, presence of carbofuran into the fish body was confirmed.

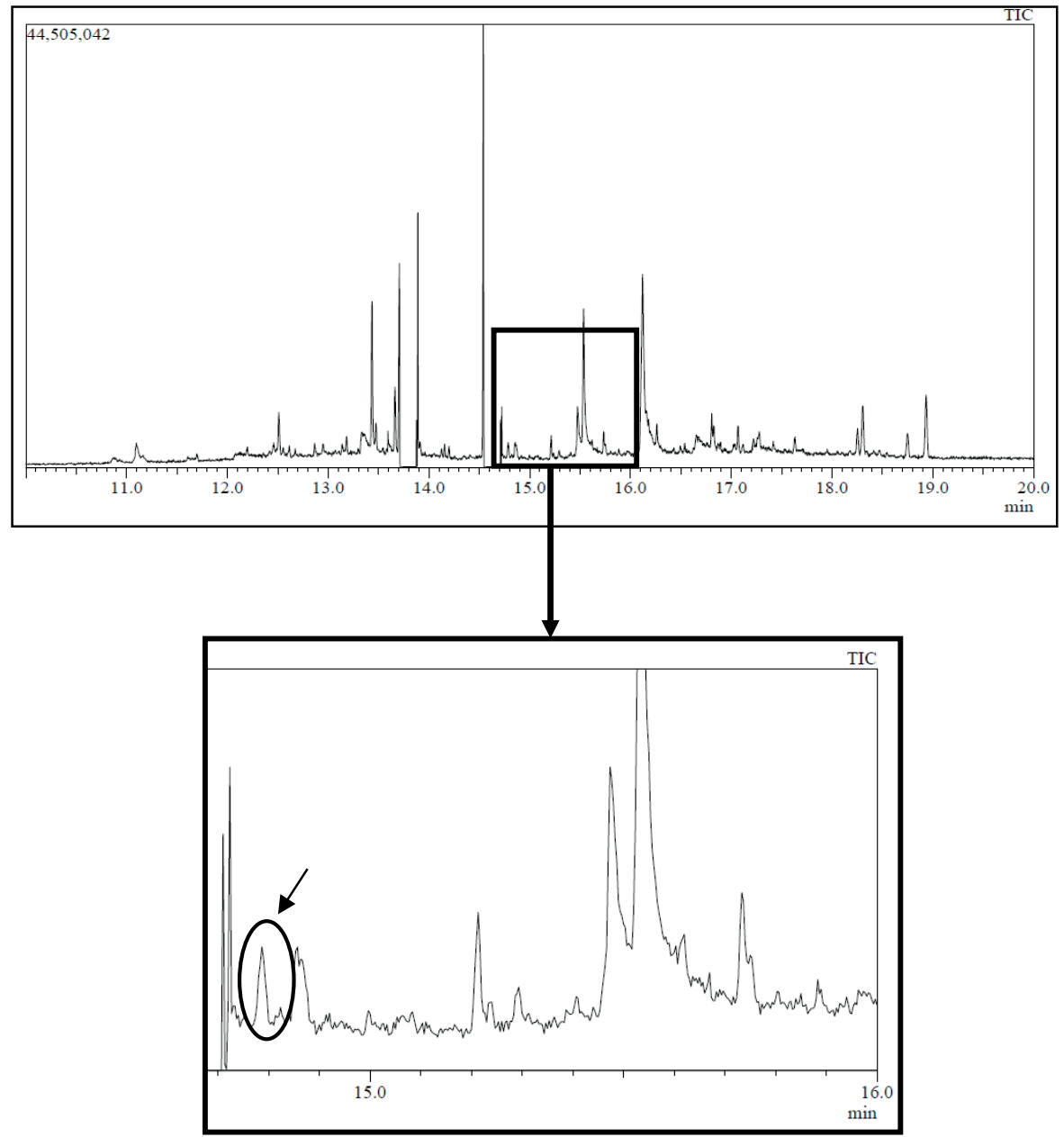

Figure 1. GC-MS chromatogram from muscle sample of tench exposed to $100 \mu \mathrm{g} / \mathrm{L}$ of carbofuran. The circle shows the carbofuran peak, appeared after a retention time of $14.787 \mathrm{~min}$. 

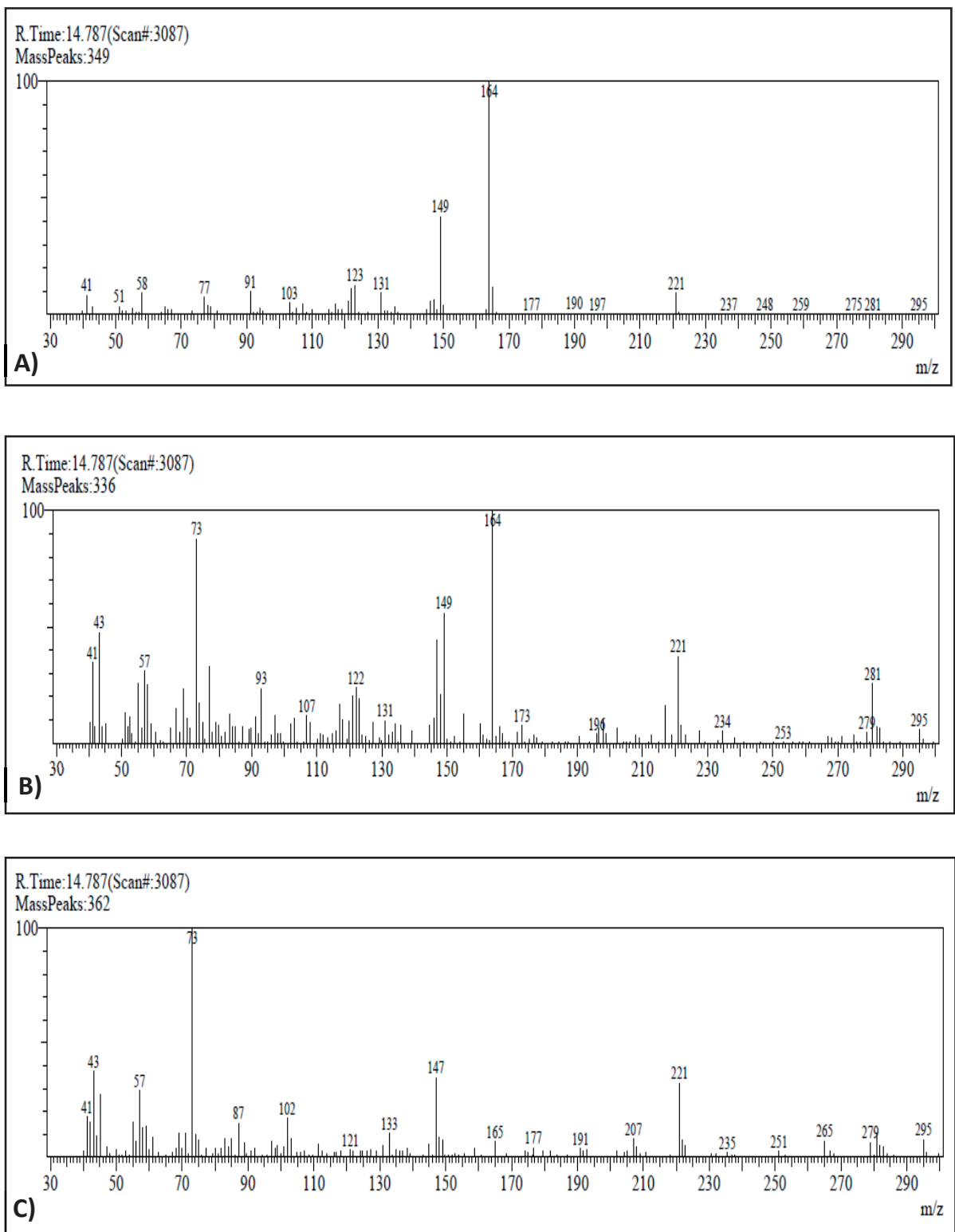

Figure 2. Mass spectrum from the peak appeared at retention time: $14.787 \mathrm{~min}$, corresponding to the chromatograms obtained of carbofuran standard (A), muscle from fish exposed to $100 \mu \mathrm{g} / \mathrm{L}$ of carbofuran (B), and muscle from control fish (C).

Figure 3A shows LPO levels, measured as MDA concentration, in the brain of pesticide-exposed and control groups, expressed as \% of control values. MDA levels were similar among groups until day 14. The MDA concentration was significantly decreased $(\mathrm{p}<0.05)$ in fish exposed to $100 \mu \mathrm{g} / \mathrm{L} \mathrm{CF}$ after 14 and 28 days of the experiment (52.87 and $48.82 \%$ of decrease, respectively).
Afterwards, with the highest concentration $(200 \mu \mathrm{g} / \mathrm{L})$, there were three decreases in MDA content of $48.36,61.78$, and $62.97 \%$ at 14,21 , and 28 days of experiment, respectively, in all cases statistically significant $(\mathrm{p}<0.05)$. Moreover, animals exposed to $100 \mu \mathrm{g} / \mathrm{L}$ also showed a transient significant induction of MDA ( $p<0.05) 7$ days after the beginning of the exposure (in that case related to an increase of $63.47 \%$, when compared to the control). 


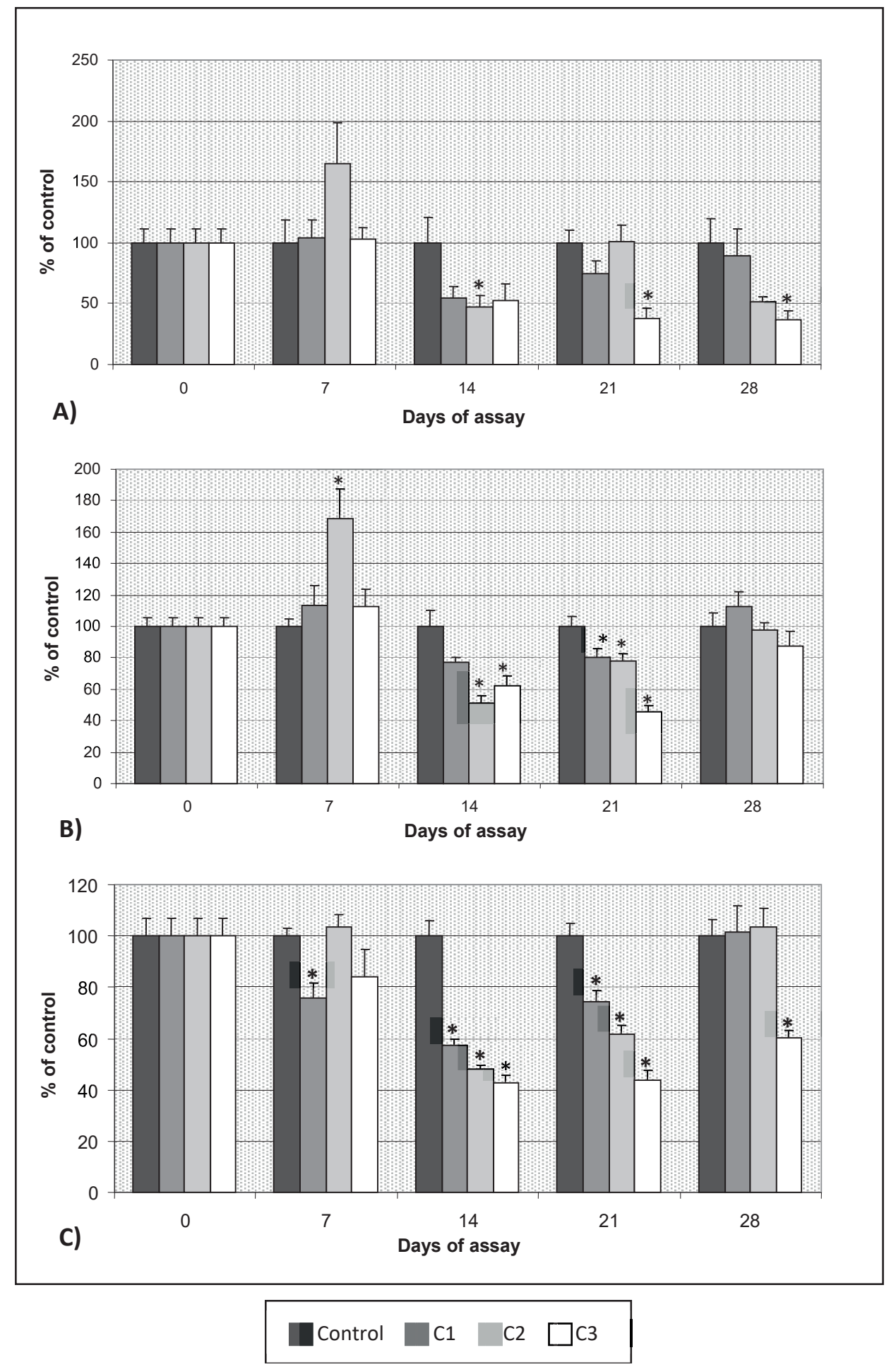

Figure 3. A) MDA, B) GSH and C) AChE levels in brain (mean $\pm \mathrm{SE}$ ) of tench exposed to carbofuran, expressed as percentage of control (100\%). *: statistically significant with respect to the control at the same sampling day (p<0.05). C1: $50 \mu \mathrm{g} / \mathrm{L} ; \mathrm{C} 2$ : $100 \mu \mathrm{g} / \mathrm{L}$ and $\mathrm{C} 3: 200 \mu \mathrm{g} / \mathrm{L}$ of carbofuran. 
Regarding non-enzymatic antioxidant mechanism $(\mathrm{GSH})$, increased $(\mathrm{p}<0.05)$ values were observed in fish exposed to $100 \mu \mathrm{g} / \mathrm{L}$ at 7 days of exposure when compared to control fish (Figure 3B). However, after 14 and 21 days those differences corresponded to decreased values of GSH. At 14 days of experiment, GSH levels decreased to 49.13 and $37.72 \%$ when compared to controls, with concentrations of 100 and $200 \mu \mathrm{g} / \mathrm{L}$, respectively $(\mathrm{p}<0.05)$. Similarly, after 21 days, GSH levels decreased to 21.81 and $53.95 \%$ of control, for these two same doses of 100 and $200 \mu \mathrm{g} / \mathrm{L}$, respectively. Nevertheless, and unlike that observed to MDA, GSH recovered to control levels after 28 days of exposure.

AChE activity results are shown in Figure 3C. Differences with the control group were observed since the beginning of the experiment, with the inhibition of $24.16 \%$ in fish exposed to $50 \mu \mathrm{g} / \mathrm{L}$ for 7 days. Fish exposed to all the concentrations, sampled at days 14 and 21, showed inhibited AChE activity $(p<0.05)$. The highest inhibition occurred with $200 \mu \mathrm{g} / \mathrm{L}$ of carbofuran; this effect persisted until the end of the experiment. The inhibition caused by 50 and $100 \mu \mathrm{g} / \mathrm{L}$ was totally reverted at day 28 after exposure.

Regarding Pearson's test, a positive correlation between AChE activity and MDA levels ( $r=0.345$, $\mathrm{p}<0.05$ ) was observed in control fish, being strongly significant the positive correlation found in fish exposed to $200 \mu \mathrm{g} / \mathrm{L}$ of $\mathrm{CF}(\mathrm{r}=0.485, \mathrm{p}<0.01)$. Regarding the relationship between MDA and GSH, a strong positive correlation appeared only in the control group $(\mathrm{r}=0.546, \mathrm{p}<0.001)$, indicating possible disturbance in the oxidative stress complex after exposure to carbofuran.

\section{Discussion}

Tenchs showed decreased HIS at the end of the exposure period with all the tested concentrations. This effect was also found by Ram and Singh (1988) in Channa punctatus after 6 months of exposure to $996 \mathrm{mg} / \mathrm{L}$ of carbofuran. Those authors pointed out to a possible histopathological induction and biochemical alteration in liver that may cause physiometabolic dysfunction in this species, which can be extended to tench. As aquatic organisms have developed several cellular defense paths, which under normal metabolic conditions protect against the deleterious effects of chemical contaminants, lipid peroxidation and GSH levels are directly related to oxidative stress enzymatic activities. Variation in those biochemical parameters may result from stress situations, but susceptibility of the species should be also taken into account. The increase in xenobiotic concentration may not be always related to an induction of antioxidant activity since several factors can influence this effect (Hernández-Moreno et al., 2008). That idea is in accordance with the different effect on GSH levels showed by our tenchs exposed to $100 \mu \mathrm{g} / \mathrm{L}$, increased at 7 days and decreased after 14 and 21 days of experiment.

Increased GSH levels observed in controls can be due to several exogenous factors more than exposure to pesticides, i.e. change of habitat (Sarkar et al., 2006). In this sense, a comparison of every exposed group with the control one is of great importance to identify the real effect of xenobiotics, since physiological levels can be modified along the time.

Several studies mentioned GSH levels as a useful tool for oxidative stress evaluation in fish, and more specifically cytotoxicity of some carbamates is correlated with the decrease in GSH content (Hernández-Moreno et al., 2010). An increase of glutathione levels was reported in catfish (Ictalurus punctatus) and marine fish exposed to sediments containing polycyclic aromatic hydrocarbon (PAH) (Di Giulio et al., 1993). Generally, antioxidant system induction indicates an adaptability response, thus allowing to overcome oxidative stress due to chemical exposure. Doyotte et al. (1997) and Zhang et al. (2004) reported increased GSH levels during a moderate oxidative stress process as an adaptation mechanism through the increase in its synthesis. Additionally, other biochemical responses can be seen after exposure to environmental contaminants. For example, suppression of GSH due to loss of adaptation mechanism and oxidation to GSSG after exposure to xenobiotics was reported by Zhang et al. (2004). In our study, a decreased GSH appeared after 14 days of the experiment; and similarly Ghosh et al. (1993) reported a time-related decrease in GSH levels in fish exposed to carbaryl, indicating that non-lethal concentrations are higher enough to deplete GSH. 
Some authors consider GSH depletion as the main cause for a reduction of the free radical scavenging capacity of cells (Sevgiler et al., 2007; Kavitha and Rao, 2009), with LPO (measured as MDA levels) appearing closely related to GSH reductions. It has been suggested that many pollutants such as pesticides are capable of inducing oxidative stress through overproduction of reactive oxygen species (ROS): oxidative stress causes damage to cellular macromolecules such as nucleic acids, proteins and lipids, and lipid peroxidation has been suggested to be one of the molecular mechanisms involved in the cytotoxicity of carbamates (Üner et al., 2009). In fact, a general increase of MDA levels is usually associated to carbamate exposure (HernándezMoreno et al., 2008; Ghosh et al., 1993). However, a clear inhibition of brain MDA levels has been obtained in the present study, thus indicating a decrease in the rate of lipid peroxidation. This is not an unusual finding; similar decreased levels of LPO were found by Üner et al. (2009) with fish exposed to organophosphates, whereas Song et al. (2006) showed the brain as the most sensitive organ to oxidative damage. Similarly, several authors reported brain as extremely susceptible to oxidative stress due to its high polyunsaturated fatty acids content, which quickly suffer peroxidation linked to a low antioxidant capacity (Sharma et al., 2005, Ballesteros et al., 2009). But the exposure concentration of the assay can clearly influence the brain LPO, as some previous experiments with tench exposed to carbofuran have demonstrated (Hernández-Moreno et al., 2010), thus reflecting that higher carbofuran levels are needed to observe an effect on LPO. This idea is supported by the lack of effect in MDA levels observed in carps when they were exposed to carbofuran for 15 and 30 days on a continuous flow, at $100 \mu \mathrm{g} / \mathrm{L}$ as the highest concentration (Ensibi et al., 2014). Nevertheless, those authors reported an early decrease after only 4 days of exposure, with a following recovery of MDA levels. In our study, it seems that the already known inversely correlation between MDA and GSH levels only appears after a long term exposure to carbofuran.

Brain AChE sensitivity towards several inhibitors has been used as a biomarker to identify organophosphate and carbamate exposure since 1970 (Payne et al., 1996; Fulton and Key, 2001). However, this inhibition is not always reached; as reported by
Fernández et al. (1996) in a study with gilt-head bream exposed to malathion, where no differences appeared between control and exposed fish. Nevertheless, inhibition of $50 \%$ due to organophosphates and carbamates would indicate toxicity (Dembélé et al., 2000).

Depending on the species, some fish can survive with high levels of AChE inhibition, whereas other species die at the same concentrations. In this sense, carps exposed to fenthion survived even with inhibition of $90 \%$ (Üner et al., 2009), as well as $C$. auratus and carps exposed to carbofuran (Bretaud et al., 2000; Clasen et al., 2014), with AChE inhibition of up to $87 \%$. Nevertheless, $70-80 \%$ of AChE inhibition is generally assumed as cause of death (Bradbury et al., 2008). That variability may be due to absorption, as well as metabolic and physiological factors, or different biochemical properties of the enzymes. Moreover, recovery of basal levels is different depending of the anticholinergic chemicals; therefore, effects of pesticides can differ depending on several factors (Ferrari et al., 2004).

In agreement with our results, other authors have reported neurotoxic effects along the time associated to acute or repeated exposure to high concentrations of carbamates (Moreno-Grau, 2003). The AChE activity pattern is similar to that reported by Wang et al. (2009), who developed a study with $C$. auratus exposed to propoxur for 15 days, showing a recovery period. The AChE activity of our animals recovered to basal levels the last day of the experiment at the lowest concentrations assessed, something reported also in C. auratus (Ferrari et al., 2004). Barata et al. (2004) also found recovery of AChE levels in Daphnia magna, being more rapid the recovery after exposure to carbamates than organophosphates. Moreover, when the inhibition is due to carbamate exposure, the reactivation of the enzyme appears spontaneously in a short period of time, helped by the rapid synthesis and release of new enzyme from the liver (Blaber and Creasey, 1960; Thompson, 1999). This suggests that a chronic exposure to some chemicals may trigger a physiological adaptation in aquatic organisms, inducing compensatory mechanisms.

In the present study, fish recovered basal AChE levels with no need of being transferred to pesticide- 
free waters, possibly due to adaptation or higher enzymatic synthesis facing to long-term exposure to low concentrations of carbofuran, as reported in previous experiments with fish exposed to lower concentrations for more than 30 days (HernándezMoreno et al., 2010). Therefore, the link between recovery potential and concentration and time after exposure to a pesticide is confirmed (Kristoff et al., 2006). Indeed, the toxicity of carbofuran is highly dependent on the length, frequency and intensity of exposure, as well as the susceptibility of the organism tested, the latter being influenced by age, gender and genetic variation (Lannacone and Tejada, 2007).

As expected, AChE activity decreased as pesticide concentration and time of exposure increased, according to the results reported by Feng et al. (2008), Cong et al. (2009), and Clasen et al. (2014) in experiments with organophosphates and carbamates. Bretaut et al. (2000) also reported the same pattern, showing recovery of AChE levels at $50 \mu \mathrm{g} / \mathrm{L}$ after 14 days of exposure. Recovery of AChE levels may be influenced by several exogenous factors (time, temperature, salinity), as reported by GholamiSeyedkolaei et al. (2013); therefore, it is of great importance to maintain the experiment under controlled conditions.

The increase in the acetylcholine concentration due to inhibition of AChE by carbofuran, leads to hypercholinergic excitatory processes and increases the rate of oxygen flow through brain and muscle, followed by a high increase in ATP consumption, much higher than its rate of production. This metabolic alteration has been described as a cause for reactive oxygen species production (Rai et al., 2011; Jaiswal et al., 2013), showing the relationship between neurotoxic and oxidative stress biomarkers. In fact, other similar studies with low concentrations of carbofuran have detected disruption of normal metabolism in fish organs, rendering antioxidant responses as biomarkers of carbamate exposure, together with AChE in brain (Clasen et al., 2014).

Our results demonstrate that the pesticide carbofuran may cause changes in some biochemical parameters of tench under laboratory conditions. In fact, changes in the three parameters assessed (but mainly inhibition of AChE activity) could be used as biomarkers of short exposure (less than 14 days) to carbamates in biomonitoring programs, whereas MDA reduction could also be associated with longer exposure to low concentrations of pesticides. The measurement of such parameters in brain samples could be taken into consideration to monitor insecticide toxicity to fish living in contaminated waters.

\section{Acknowledgments}

This research was supported by the Spanish Government within the framework of the project "PCI-Programa de Cooperación Interuniversitaria Túnez-España" (references A/015933/08 and $\mathrm{A} / 024757 / 09)$. We are grateful to the Extremadura regional government (Consejería de Industria, Energía y Medio Ambiente, Junta de Extremadura) for supplying the fish used in the study.

\section{Conflict of interest}

The authors declare no conflicts of interest with regards to the work presented in this article.

\section{References}

Abdollahi M, Ranjbar A, Shadnia S, Nikfar S, Rezaie A. Pesticides and oxidative stress: a review. Med Sci Monit 2004; 10(6): 141-147.

Anderson ME. Glutathione: an overview of biosynthesis and modulation. Chemico-Biol Interact 1998; 111-112: 1-14.

APHA/AWWA/WPCF. Métodos Normalizados Para el Análisis de Aguas Potables y Residuales. Madrid (Spain): Ed. Díaz de Santos; 1992.

Ballesteros ML, Wunderlin DA, Bistoni MA. Oxidative stress responses in different organs of Jenynsia multidentata exposed to endosulfan. Ecotoxicol Environ Saf 2009; 72: 199-205.

Barata C, Solayan A, Porte C. Role of B-esterases in assessing toxicity of organophosphorus (chlorpyrifos, malathion) and carbamate (carbofuran) pesticides to Daphnia magna. Aquat Toxicol 2004; 66: 125-139.

Blaber LC, Creasey NH. The mode of recovery of cholinesterase activity in vivo after organophosphorus poisoning. Biochem $\mathrm{J}$ 1960; 77: 597-604.

Bradbury SP, Carlson RW, Henry TR, Padilla S, Cowden J. Toxic responses of the fish nervous system. In: Di Giulio RT, Hinton DE, editors. The Toxicology of Fishes. Florida: Taylor \& Francis CRC Press; 2008; p. 417-455. 
Bradford M. A rapid and sensitive method for the quantification of microgram quantities of protein utilizing the principle of proteindye binding. Anal Biochem 1976; 72: 248-254.

Bretaud S, Toutant JP, Saglio P. Effects of carbofuran, diuron, and nicosulfuron on acetylcholinesterase activity in goldfish (Carassius auratus). Ecotoxicol Environ Saf 2000; 47: 117-124.

Chen L, Yu K, Huang C, Yu L, Zhu B, Lam PK, Lam JC, Zhou B. Prenatal transfer of polybrominated diphenyl ethers (PBDEs) results in developmental neurotoxicity in zebrafish larvae. Environ Sci Technol 2012; 46: 9727-9734.

Clasen B, Leitemperger J, Murussi C, Pretto A, Menezes Ch, Dalabona F, Marchezan E, Adaime M, Zanella R, Loro VL. Carbofuran promotes biochemical changes in carp exposed to rice field and laboratory conditions. Ecotoxicol Environ Saf 2014; 101: 77-82.

Council Directive 86/609/EEC (1986) on the approximation of laws, regulations and administrative provisions of the Member States regarding the protection of animals used for experimental and other scientific purposes.

Cong NV, Phuong NT, Bayley M. Effects of repeated exposure of diazinon on cholinesterase activity and grow thin snake head fish (Channa striata). Ecotoxicol Environ Saf 2009; 72: 699-703.

Dembélé K, Haudruge E, Gaspar C. Concentration effects of selected insecticides on brain acetylcholinesterase in common carp (Cyprinus carpio L). Ecotoxicol Environ Saf 2000, 45: 49-54.

Di Giulio RT, Habig C, Gallagher EP. Effects of Black Rock Harbor sediments on indices of biotransformation, oxidative stress, and DNA integrity in channel catfish. Aquat Toxicol 1993; 26: $1-22$.

Doyotte A, Cossu C, Jacquin MC, Babut M, Vasseur P.. Antioxidant enzymes, glutathione and lipid peroxidation as relevant biomarkers of experimental or field exposure in the gills and the digestive gland of the freshwater bivalve Unio tumidus. Aquat Toxicol 1997; 39: 93-110.

Eissa BL, Salibian A, Ferrari L, Porta P, Borgnia M. Evaluación toxicológica no invasiva del cadmio, modificaciones de biomarcadores conductuales en Cyprinus carpio. Rev Biol Acuát 2003; 20: 56-62.

Ellman GL, Courtney KD, Andres V, Featherstone, RM. A new and rapid colorimetric determination of cholinesterase activity. Biochem Pharmacol 1961; 7: 88-95.

Ensibi C, Hernández-Moreno D, Míguez MP, Daly MN, Soler F, Pérez-López M. Effects of carbofuran and deltamethrin on acetylcholinesterase activity in brain and muscle of the common carp. Environ Toxicol 2014; 29(4): 386-393.

Feng T, Li ZB, Guo XQ, Guo JP. Effects of trichlorfon and sodium dodecyl sulphate on antioxidant defense system and acetylcholinesterase of Tilapia nilotica in vitro. Pest Biochem Physiol 2008; 92: 107-113.

Fernández C, Boleas S, Carbonell G, Tarazona JV, Martin-Otero LE, García MA. Estudio de aplicación de algunos biomarcadores convencionales en doradas (Sparus aurata). Investig Agrar Prod San Animal 1996; 11(3): 235-242.

Ferrari A, Venturino A, De D'angelo AM. Time course of brain cholinesterase inhibition and recovery following acute and subacute azinphosmethyl, parathion and carbaryl exposure in the goldfish (Carassius auratus). Ecotoxicol Environ Saf 2004; 57: 420-425.

Fulton MH, Key PB. Acetylcholinesterase inhibition in estuarine fish and invertebrates as an indicator of organophosphorus insecticide exposure and effects. Environ Toxicol Chem 2001; 20: 37-45.

Gholami-Seyedkolaei SJ, Mirvaghefi A, Farahmand H, Kosari AA, Gholami-Seyedkolaei SJ. Gholami-Seyedkolaei SJ. Optimization of recovery patterns in common carp exposed to roundup using response surface methodology: evaluation of neurotoxicity and genotoxicity effects and biochemical parameters. Ecotoxicol Environ Saf 2013; 98(1): 152-161.

Ghosh P, Ghosh S, Bose S, Bhattacharya B. Glutathione depletion in the liver and kidney of Channa punctatus exposed to carbaryl and metacid-50. Sci Total Environ 1993; 134(1): 641-645.

Hernández-Moreno D, Soler F, Miguez MP, Pérez-López M. Hepatic monooxygenase (CYP1A and CYP3A) and UDPGT enzymatic activities as biomarkers for long-term carbofuran exposure in tench (Tinca Tinca L). J Environ Sci Health B 2008; 43: 395- 404 .

Hernández-Moreno D, Soler F, Miguez MP, Pérez-López M. Brain acetylcholinesterase, malondialdehyde and reduced glutathione as biomarkers of continuous exposure of tench, Tinca tinca, to carbofuran or deltamethrin. Sci Total Environ 2010; 408: 4976-83.

Hissin PJ, Hilf R. A fluorometric method for determination of oxidized and reduced glutathione in tissues. Anal Biochem 1976; 74(1): 214-226.

Jaiswal SK, Siddiqi NJ, Sharma B. Carbofuran imbalances the redox status in rat brain, amelioraton by vitamin C. J Biochem Res 2013; 1(4): 36-43.

Kanno S, Matsukawa E, Miura A, Shouji A, Asou K, Ishikawa M. Diethyldithiocarbamate-induced cytotoxicity and apoptosis in leukemia cell lines. Biol Pharm Bull 2003; 26: 964-968.

Kavitha P, Rao JV. Sub-lethal effects of profenofos on tissue-specific antioxidative responses in a Euryhyaline fish, Oreochromis mossambicus. Ecotoxicol Environ Saf 2009; 72: 1727-1733.

Kristoff G, Guerrero NV, de D'Angelo AM, Cochon, A.C. Inhibition of cholinesterase activity by azinphos-methyl in two freshwater invertebrates, Biomphalaria glabrata and Lumbriculus variegatus. Toxicol 2006; 222(3): 185-194.

Lannacone J, Tejada M. Employment of regeneration of freshwater planarian Girardia festae (Borelli, 1898) (Tricladida: dugesiidae) to evaluate toxicity of carbofuran. Neotrop Helminthol 2007; 1(1): 7-13.

Li Z, Lu G, Yang X, Wang C. Single and combined effects of selected pharmaceuticals at sublethal concentrations on multiple biomarkers in Carassius auratus. Ecotoxicol 2011; 21: 353-361. 
Livingstone DR. Contaminant-stimulated reactive oxygen species production and oxidative damage in aquatic organisms. Mar Pollut Bull 2001; 42: 656-66.

Moreno-Grau MD. Toxicología Ambiental. Evaluación de riesgo para la salud humana. Madrid: Ed. McGraw Hill/Interamericana; 2003.

OECD. Test 305, Bioconcentration, Flow-through Fish Test', in OECD Guidelines for Testing of Chemicals. 1996, http://www. oecd-ilibrary.org/environment/test-no-305-bioconcentration-flowthrough-fish-test_9789264070462-en (accessed 1 October 2013).

Payne JF, Mathieu A, Melvin W, Fancey LL. Acetylcholinesterase, an old biomarker with a new future? Field trials in association with two urban rivers and a paper mill in Newfoundland. Mar Pollut Bull 1996; 32: 225-231.

Picó Y, Moltó JC, Redondo MJ, Viana E, Mañes J, Font G. Monitoring of the pesticide levels in natural waters of the Valencia community (Spain). Bull Environ Contam Toxicol 1994; 53(2): 230-237.

Rai DK, Sharma RK, Rai PK, Watal G, Sharma B. Role of aqueous extract of Cynodon dactylon in prevention of carbofuran- induced oxidative stress and acetylcholinesterase inhibition in rat brain. Cell Mol Biol 2011; 57(1): 135-42.

Ram RN, Singh SK. Carbofuran-induced histopathological and biochemical changes in liver of the teleost fish, Channa punctatus (Bloch). Ecotoxicol Environ Saf 1988; 16(3): 194-201.

Recknagel RO, Glende EA, Walker RL, Lowery K. Lipid peroxidation biochemistry measurement and significance in liver cell injury. In: Plaa GL, Hewitt WR, editors. Toxicology of the Liver. New York: Raven Press; 1982; p. 218-232.
Sarkar A, Ray D, Shrivastava AN. Molecular biomarkers: their significance and application in marine pollution monitoring. Ecotoxicol 2006; 15: 333-340.

Sevgiler Y, Poner P, Durmaz H, Üner N. Effects of N-acetylcysteine on oxidative responses in the liver of fenthion exposed Cyprinus carpio. Pest Biochem Physiol 2007; 87: 248-254.

Sharma Y, Bashir S, Irshad M, Gupta SD, Dogra TD. Effects of acute dimethoate administration on antioxidant status of liver and brain of experimental rats. Toxicol 2005; 206: 49-57.

Song SB, Xu Y, Zhou BS. Effects of hexachlorobenzene on antioxidant status of live rand brain of common carp (Cyprinus carpio). Chemosphere 2006; 65: 699-706.

Thompson HM. Esterases as markers of exposure to organophosphates and carbamates. Ecotoxicol 1999; 8: 369-384.

Tor ER, Holstege DM, Galey FD. Determination of cholinesterase activity in brain and blood samples using a plate reader. J AOAC Int 1994; 77(5): 1308-1313.

Üner N, Sevgiler Y, Durmaz H, Piner P, Çınkıloğlu E. $\mathrm{N}$-Acetylcysteine provides dose-dependent protection against fenthion toxicity in the brain of Cyprinus carpio L. Comp Biochem Physiol C 2009; 150: 33-38.

Wang C, Guanghua L, Jing C, Peifang W. Sublethal effects of pesticide mixtures on selected biomarkers of Carassius auratus. Environ Toxicol Pharmacol 2009; 28: 414-419.

Zhang J, Shen H, Wang X, Wu J, Xue Y. Effects of chronic exposure of 2,4-dichlorophenol on the antioxidant system in liver of freshwater fish Carassius auratus. Chemosphere 2004; 55: $167-174$. 